\title{
Advancing İznik tiles to the 21st century by applying nano structured materials
}

\author{
E. Gunay ${ }^{1}$, M. Sariguzel ${ }^{1} \&$ C. Imer $^{2}$ \\ ${ }^{I}$ TUBITAK MRC Materials Institute, Kocaeli, Turkey \\ ${ }^{2} I T U$, Faculty of Chemical and Metallurgical Engineering, \\ Department of Metallurgical and Materials Engineering, PML Lab, \\ Istanbul, Turkey
}

\begin{abstract}
Nanotechnology actually started in the 9th century in Mesopotamia with a lustre layer on ceramic surfaces applied by ceramic artists. Reducing atmosphere lusters are classified into two groups, due to preparation and implementation, as in-glaze and over-glaze lusters. Over-glaze luster is a kind of decoration and inglaze luster is a kind of glaze. Cooling is achieved in reducing the atmosphere for both types of lusters and the nano particles give the luster effect. Traditional İznik tiles were produced in İznik from the 14th century to the 17 th century. These ceramics are known as "unproducible" due to their high quartz content, composition and unique processing steps. The production of İznik ceramics stopped in 1716 due to unknown reasons with no written documents about their production being left. TUBITAK MRC and the İznik Foundation are carrying out an important experimental project to improve and understand the effects of nanotechnology application in İznik ceramics. In this study, the high quartz content of İznik ceramics is kept as it is and nanotechnology is applied at the decoration stage as nanometer sized pigments and as nanometer sized metallic particles in glazes for a luster effect. A comparison is carried out between traditional and modern İznik ceramics in colour, brightness and other properties by SEM and XRD characterisation techniques.

Keywords: İnik tiles, nano technology, nanometer sized pigments, lustre.
\end{abstract}




\section{Introduction}

Cultural heritage is unique and irreplaceable, which places the responsibility of preservation on the current generation. Cultural property includes buildings and historic places, monuments, books, documents, works of art, machines, clothing, and other artefacts, that are considered worthy of preservation for the future. Traditional İznik tiles and lusterwares are two of the important cultural heritage objects which provide a concrete basis for ideas, and their preservation demonstrates recognition of the necessity of the past and of the things that tell its story for the ceramist. İznik is located on the banks of the lake of the same name in the province of Bursa in the north western part of Anatolia in Turkey. In the course of its history from $316 \mathrm{BC}$ to the present day; İznik is an archaeological and historical art laboratory of the Romans, Byzantines, Seljuk and Ottoman Turks. Islamic ceramic art reached the pinnacle of its splendour with the production of pottery and tiles referred as "Çini" in Ottoman documents in İznik (Nicea) between the 15 th and early 18 th centuries [1]. 70-80\% of an İznik tile is composed of quartz and one can observe colours resembling those of semiprecious stones such as the dark blue of lapis lazuli, the blue of turquoise, the redness of coral and the green of emerald. The figures on the tiles and utensils reflect allegorical and symbolic characteristics, the flora and fauna of the region. The inscriptions and the writings on the tiles never consist of egocentric or aggressive texts; rather, they present the ideology and philosophy of Islam. Traditional İznik tiles contain 4 different layers as "body, slip, decors and glaze" and each one has special starting materials and preparation techniques. After quartz body is formed, it was coated with a slip similar in composition to the paste and providing a perfect "fit" to the body. The under glaze decoration with cobalt blue, copper turquoise, or iron red is applied to this slip coating after a drying or initial firing process of the body. Finally tiles are covered with a lead alkali silicate glaze [1].

The words nanotechnology and cultural heritage would often be used in the same sentence in recent years because of the new identification equipment which allow to study, understand and manipulate matter at the atomic level. In recent years the chemistry of the lusterware process is identified by a group of researchers with the help of the new nano technological devices [2]. Luster is a ceramic design with a golden or coppery metallic shine first produced in early Islamic times $\left(9^{\text {th }}\right.$ century AD in Iraq) that extended all over the Mediterranean and lasted until the first half of the $20^{\text {th }}$ century AD [3]. According to the literature of recent studies; lustre glazes are reported as the metal-glass nano composite thin layer composed by dispersing copper or silver nano particles in silica based glassy matrix [4]. Mainly, lusters are divided into two groups as oxidizing and reducing atmosphere lustre [5]. Oxidizing atmosphere lusters are developed with rezinats (resins, oils) that have regional reducing act in oxygen rich oxidizing atmosphere. Reducing environment provided by the formation of carbon monoxide from flammable fumes like wet wood, sawdust, oil, naphthalene or by introducing gas to the furnace. Reducing atmosphere lusters are classified into two groups due to preparation and implementation: 1. Reduced 
glaze lusters (in-glaze lusters), 2. Reduced pigment (clay-pastes) lusters (overglaze lusters).

Reduced glaze lusters or in-glaze lusters are prepared with adding copper, iron, cobalt, manganese, silver, bismuth compounds in different amounts directly to the glaze. After glaze firing, by a reduction during cooling process, a lustre effect appears on the surface of glaze. Reduced pigment lustre or over-glaze lustre is produced by direct application of a raw paint (powder mixture containing clay, copper and/or silver compounds) over a glazed ceramic which after firing in a reducing atmosphere results in the formation of a lustre layer. Cooling is made in reducing atmosphere for both type of lusters and nano particles give the lustre effect. The main difference between these two methods is the ware produced with in-glaze method does not to be cleaned after firing. Wood and gas fired furnaces used in reducing atmosphere lusters, electric heated furnaces preferred for oxidizing atmosphere lusters [5]. Furnace atmosphere, temperature and the composition of the glaze, metal oxides, pigments and the clay are effective and important elements for the production process of the lustre. The colour and transparency of lustre thin layer or in-glaze lusters depend on light absorption and reflection and the glazed ceramic surface exhibits metallic golden or coppery images. Our Research Group in the Materials Institute of TUBITAK MRC in Turkey have been working intensively to rake over the ashes of the past and to use nano technological approach on historical artefacts in recent years. In this context, one of on-going project is concerned to produce İznik tiles with modern methods, to apply nano size pigments on under glaze decoration of İznik tiles in order to see the effect of nanotechnology application, to understand the lustre technique and finally to produce new İznik tiles with lustre decoration. This paper outlines some of the results of this on-going project sponsored by The Scientific and Technological Research Council of Turkey (TUBITAK).

\section{Experimental}

There are 4 milestones of the project experiments. First; İznik tiles were produced with modern production methods, second; nanometer sized paints were applied on decoration stage. On the third step of the project; lustre material was added inside the İznik glaze (in-glaze luster ) and finaly luster paste was applied over the İznik glaze (over-glaze luster).

\section{Results and discussion}

\subsection{Production of İznik tiles}

Production process of İznik tiles involves grinding of raw materials, preparation of body mixture, shaping, drying, firing, glazing and glost firing. Four different layers as "body, slip, decors and glaze" of İznik ceramics have some special starting materials and preparation techniques. For the preparation of body and slip layers of İznik tiles; glass, grog, sodium feldspar, zirconium silicate, zinc 
oxide and frit were used. A hydraulic dry press was used to produce the body (masse) in the form of plates by applying $45 \mathrm{bar} / \mathrm{cm}^{2}$ pressure. Slip slurry was poured over the surface of pressed tiles and bisque firing was performed at $1000^{\circ} \mathrm{C}$. Lead-alkali glaze/frit was used for glazing and glost firing was applied at $950^{\circ} \mathrm{C}$. Chemical analysis of body, slip and the glaze are given in table 1. It is known that to achieve a well-fitting glaze, the expansion of the glaze and body should be more or less equal. Thermal expansion coefficients $(\alpha)$ of body, slip and glaze (frit) of İznik tiles were measured in static air atmosphere by Netzsch Dilatometer (DIL 402C/ 3/ F) with a heating rate of $5^{\circ} \mathrm{C} \mathrm{min}^{-1}$. TECs of body, slip and frit are $8.41,8.48$ and $8.32 \times 10^{-6} \mathrm{~K}^{-1}$ respectively between $33-100^{\circ} \mathrm{C}$ and they are very close to each other.

Table 1: Chemical analysis of an İznik tile before firing (by WDXRF).

\begin{tabular}{cccc}
\hline \multicolumn{3}{c}{ Amount (as wt \%) } \\
\hline Oxide & Body & Slip & Glaze \\
\hline $\mathrm{Al}_{2} \mathrm{O}_{3}$ & 9.083 & 6.168 & 0.835 \\
$\mathrm{CaO}$ & 2.352 & 1.053 & 1.336 \\
$\mathrm{Fe}_{2} \mathrm{O}_{3}$ & 0.434 & 0.209 & 0.078 \\
$\mathrm{~K}_{2} \mathrm{O}$ & 0.402 & 0.220 & 0.134 \\
$\mathrm{MgO}$ & 4.978 & 1.437 & 0.470 \\
$\mathrm{Na} \mathrm{O}$ & 3.700 & 1.849 & 2.339 \\
$\mathrm{PbO}$ & 3.941 & 4.041 & 63.222 \\
$\mathrm{SiO}$ & 74.383 & 70.356 & 31.385 \\
$\mathrm{ZnO}$ & 0.027 & 3.946 & - \\
$\mathrm{ZrO}_{2}$ & 0.084 & 10.082 & 0.166 \\
\hline
\end{tabular}

$1.722 \mathrm{~g} / \mathrm{cm}^{3}$ of apparent density, $20.5 \%$ water absorption and $35 \%$ porosity for the bisques were measured by the Archimedes water displacement technique. $\mathrm{X}$-ray diffraction analysis was done to determine the main crystalline phases present in İznik tile layers. Quartz, cristobalite and feldspar are the only crystalline phases determined in body. In the slip layer, in addition to quartz, cristobalite and feldspar, zircon, lead zircon silicate are the other crystalline phases were determined. Further, there is an amorphous structure in the slip layer due to partial vitrification.

\subsection{Nanometer sized pigment application for the underglaze decoration of İznik tiles}

Recent studies showed that the production techniques and the size of pigments are important parameters in the colours of İznik tiles [6]. It is known that; the use of nanoparticles can improve the pigment performance; in the organic coatings and nanometer sized pigments enhance the tribological and mechanical properties [7]. In the sol-gel method, thermally stable and high colour performance pigments can be obtained at lower temperatures [8]. However, the sol-gel method is expensive and the process takes a long period. Besides that; 
the colours of İznik tiles are very special, unique and it is very difficult to have the similar hues with other methods. For that reason; instead of using sol-gel method, traditional pigments were reduced to nano size by introducing mechanical crushing in this study. Franco Gabrielli Technology model jet mill was used for 1-5 minutes to obtain mechanical effect. 6 different pigments were used for the preparation of paint mixtures. Particle size analysis of pigments and paints were measured with Malvern Mastersizer-X particle sizer and with Malvern Zetasizer Nano ZS 3600 equipments and results are given in table 2 and table 3, respectively. Average particle sizes of traditional and nanometersized pigments and paints were between 2.78-13.06 $\mu \mathrm{m}$ and 37.1-114 nm for pigments and in between $3.2-3.54 \mu \mathrm{m}$ and $36.4-129 \mathrm{~nm}$ for the paints, respectively.

Table 2: $\quad$ Particle size analysis results of traditional and nanometer sized pigments.

\begin{tabular}{|c|c|c|}
\hline \multirow{2}{*}{ Pigment code } & \multicolumn{2}{|c|}{$\mathrm{d}_{50}(\mu \mathrm{m})$} \\
\hline & Traditional & Nano \\
\hline Black (for contour) & 2.78 & - \\
\hline Turquoise $\left(\mathrm{Cu}_{2} \mathrm{O}\right)$ & 4.84 & 0.0371 \\
\hline Green & 6.86 & 0.0871 \\
\hline Cobalt blue & 7.98 & 0.0365 \\
\hline Yellow & 8.01 & 0.0951 \\
\hline Red & 13.06 & 0.1140 \\
\hline
\end{tabular}

Table 3: Particle size analysis results of traditional and nanometer sized paints.

\begin{tabular}{lcc}
\hline \multirow{2}{*}{ Pigment code } & \multicolumn{2}{c}{$\mathrm{d}_{50}(\mu \mathrm{m})$} \\
& Traditional & Nano \\
\hline Cobalt blue & 3.20 & 0.0364 \\
Green & 3.11 & 0.0514 \\
Turquoise & 3.54 & 0.0676 \\
Red & 3.04 & 0.1290 \\
\hline
\end{tabular}

The under glaze decoration, with traditional and nanometer sized pigments, was applied to the slip coating with a brush, after the firing process of İznik tile's body. The contours of the decoration were painted with the black pigment. The coloured areas of İznik tiles were filled in with cobalt blue, copper turquoise, or iron red paints. Finally tiles were covered with a lead alkali silicate glaze and glaze fired at $950^{\circ} \mathrm{C}$. Fig. 1 shows the final products of İznik tiles. Comparison and characterisation of İznik tiles were carried out with colour and gloss measurements. Gloss meausurements of final products were performed with Erichsen Picogloss 503 model Glossmeter according to the "ASTM D523-08 Standard Test Method for Specular Gloss. Gloss is the ability of a surface to reflect light without scattering and it is an important aspect of the colours of İznik tiles to look more vivid. It is also provide better visual perception. Gloss 
measurement by glossmeter directs a constant intensity light beam at a specific angle to the test surface and simultaneously measures the amount of reflection. Angle of illumination is the most important criterion. To clearly differentiate between high gloss and low gloss, several different measurement angles are used; among them incident angles of 20,60 and 85 degrees are the most common. According to the BYK-Gardner gloss measurement information, in order to acquire a clear differentiation over the complete measurement range from high gloss to low gloss, first the glossiness measurements of İznik tiles were made at $60^{\circ}$, surface of İznik tiles were accepted as high gloss ( $\left.>70 \mathrm{GU}\right)$ [9]. With respect to the standard; second measurement and glossiness comparison is done at $20^{\circ}$ for İznik tiles. It can be seen from table 4 that the gloss of İznik tiles were improved by using nanometersized paints instead of traditional micron sized ones.

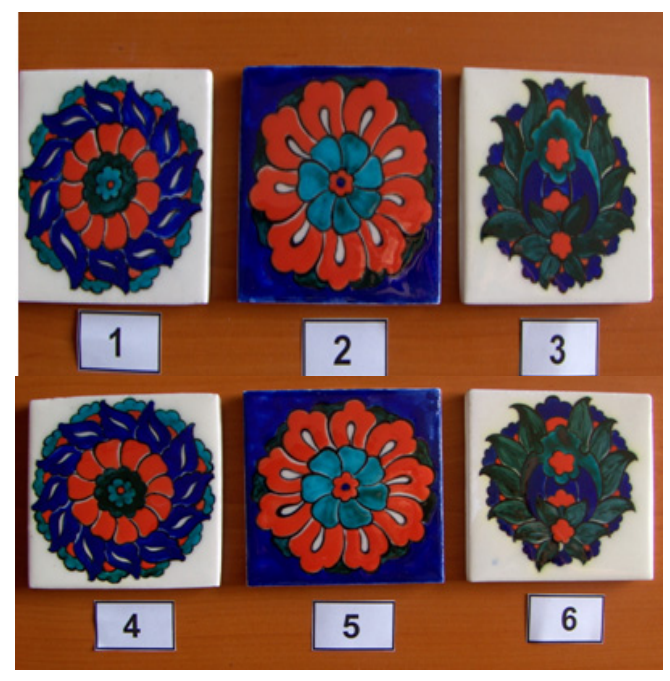

Figure 1: $\quad$ Final products (İznik tiles) (1-2-3 are decorated with traditional pigment, 4-5-6 are decorated with nanometersized pigment).

X-rite Portable SP64 Sphere Spectrophotometer was used to determine the colour ( $\mathrm{L}^{*}, \mathrm{a}^{*}$ and $\mathrm{b}^{*}$ values-CIE $\mathrm{L}^{*} \mathrm{a}^{*} \mathrm{~b}^{*}$ ) of the final products (İznik tiles) according to ASTM E313-05 standard [11]. In all colour measurements (red, cobalt blue, green and turquoise) the $\Delta \mathrm{h}$ and $\Delta \mathrm{C}$ values were positive, so it showed that nanometersized paints were more vivid and glossy than traditional one [9].

\subsection{Studies of in-glaze luster on İznik tiles}

Reduced lustre glaze or in-glaze lustre is a glaze in which the reducible metal compounds are incorporated into the glaze batch before it is fired. First, body of İznik tile was produced and slip was poured, bisque firing was performed at 
$1000^{\circ} \mathrm{C}$. Decoration is not applied during in-glaze lustre studies on İznik tiles. The particle size of the constituent ingredients is important at the melting behaviour of glaze. Therefore, a lead alkali glaze mixture (40\% water $+60 \%$ frit $+\mathrm{CMC})$ is mixed and first was ground with a ball mill for 4 hours and then was mixed for 30-40 minutes after the addition of the binder (CMC - cellulose) with a mechanical mixer. Silver carbonate was used as the main lustre ingredient to produce in-glaze lustre and it was ground in a mortar in order to have finer particle size before mixing to glaze. 5\% silver carbonate (by weight of the glaze) was added to glaze mixture. In-glaze lustre mixture was applied with a brush. Nabertherm NB300 model furnace was used for glost firing and the reduction process. First the furnace was heated until $950^{\circ} \mathrm{C}$ and glost firing-was applied for 20 minutes in oxygen atmosphere. Total glazing time was 11 hours. Subsequently for the reduction process, first the furnace was cooled down until the reduction temperature and reducing atmosphere was obtained with adding the reducing materials to the furnace. Rosewood was used as a reducing material to create an oxygen free atmosphere inside the furnace. Reduction temperature was in between $700-600^{\circ} \mathrm{C}$ and reduction time was about 5 minutes. Inlet of air (oxygen input) into the furnace blocked during reduction period to avoid distortion of lustre with re-oxidizing.

Table 4: Gloss measurements of final products (İznik tiles)-parallel and perpendicular to the brush trace of paint.

\begin{tabular}{|l|c|c|c|c|c|c|}
\hline & \multicolumn{3}{c|}{ Parallel } & \multicolumn{3}{c|}{ Perpendicular } \\
\hline \multicolumn{1}{|c|}{ Plate } & $20^{\circ}$ & $60^{\circ}$ & $85^{\circ}$ & $20^{\circ}$ & $60^{\circ}$ & $85^{\circ}$ \\
\hline Nano red paint & $\mathbf{1 1 3}$ & 113 & 99.7 & $\mathbf{1 1 3}$ & 113 & 99.7 \\
\hline Nano turquoise paint & $\mathbf{8 0 . 5}$ & 121 & 95.8 & $\mathbf{6 0 . 7}$ & 110.2 & 94.3 \\
\hline Nano cobalt blue paint & $\mathbf{9 1 . 8}$ & 114 & 97.4 & $\mathbf{6 8 . 7}$ & 80.4 & 72.1 \\
\hline Nano green paint & $\mathbf{1 1 0}$ & 115 & 100.2 & $\mathbf{8 5 . 5 6}$ & 113.1 & 97.8 \\
\hline Traditional red paint & $\mathbf{6 9 . 4}$ & 113 & 95.3 & $\mathbf{6 8 . 5}$ & 105.46 & 88 \\
\hline $\begin{array}{l}\text { Traditional turquoise } \\
\text { paint }\end{array}$ & $\mathbf{7 7 . 6}$ & 109.8 & 92.6 & $\mathbf{5 9 . 7}$ & 106.8 & 81.8 \\
\hline $\begin{array}{l}\text { Traditional cobalt blue } \\
\text { paint }\end{array}$ & $\mathbf{6 9 . 4}$ & 114.2 & 88.4 & $\mathbf{3 9 . 4}$ & 77.7 & 69.6 \\
\hline Traditional green paint & $\mathbf{6 6 . 2}$ & 113 & 92.7 & $\mathbf{4 3 . 2}$ & 93.9 & 74.2 \\
\hline
\end{tabular}

*Values were given in gloss units

**Average of 6 measurements

The pictures of an İznik tile with in-glazed luster and elemental mapping with SEM from the surface are given in Fig. 2(a) and (b), respectively. As it can be seen in-glaze lustered İznik tile demonstrates yellow iridescent colour because of the metallic silver particles. Metallic silver was also determined with the phase analysis which was done from surface of sample by X-ray diffractometer (fig. 2). Chemical analysis of the sample is given in table 5 by WDXRF spectrometer. 


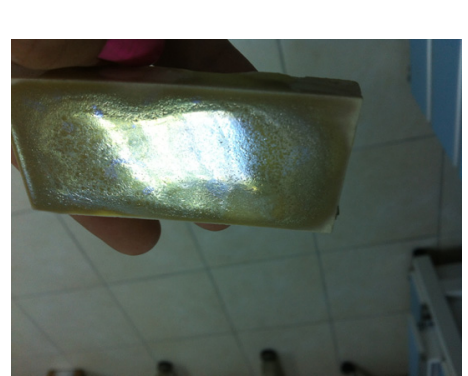

(a)

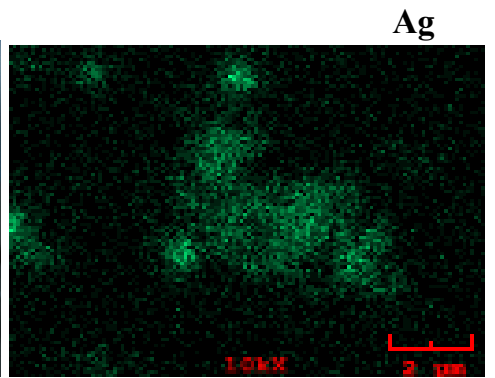

(b)

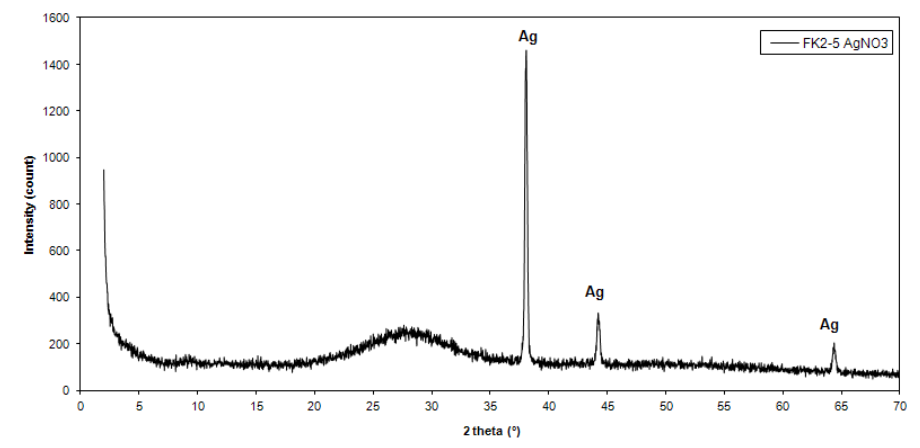

(c)

Figure 2: (a) In-glazed lustered; (b) silver elemental mapping of the sample; (c) XRD pattern of İznik tile with in-glaze luster.

Table 5: Chemical analysis of İznik tile with in glaze luster by Panalytical PW2404 model WDXRF spectrometer (wt \%).

\begin{tabular}{cccccccccc}
\hline Element & $\mathrm{Al}$ & $\mathrm{Ag}$ & $\mathrm{Ca}$ & $\mathrm{Cu}$ & $\mathrm{Fe}$ & $\mathrm{Mg}$ & $\mathrm{Na}$ & $\mathrm{Pb}$ & $\mathrm{O}$ \\
\hline$\%$ & 0.24 & 10.93 & 0.83 & 0.05 & 0.06 & 0.32 & 1.14 & $*$ & 36.78 \\
\hline
\end{tabular}

*Rest with trace amount of $\mathrm{Zn}$ and $\mathrm{Zr}$

\subsection{Studies of over-glazed luster on İznik tiles}

Over-glaze luster, sometimes referred to as reduced pigment luster, consists of silver and copper oxides in a clay carrier medium which is applied to on glaze, and after the glost firing, during cooling it is subjected to a strongly reducing atmosphere. The silver and copper oxides are reduced to their metal form and combine with the glaze surface to form a finely divided metallic film bound to the surface of the glaze. The most important feature of luster thin layer is reflecting the light as a metal surface and looking like a gold layer. Luster 
technique is extremely complex technique includes the reaction of luster paint with the glaze surface. By the reducing atmosphere in the furnace, metal ions transforms metal forms that make up nanoparticles. Reaction in over-glaze luster happens with ionic exchange of silver and copper ions with alkali ions in the glaze. These ions pass to the glaze and forms $\mathrm{Cu}^{+}$and $\mathrm{Cu}^{2+}$ for copper lusters, and $\mathrm{Ag}^{+}$and $\left(\mathrm{Ag}_{\mathrm{n}}^{\mathrm{o}}\right)^{+}$for silver lusters $[4,10]$. Several parameters are important in order to produce luster layers: the composition of the raw paint, the composition of the glaze, the thermal paths and the atmosphere. In this study; luster paint was made with the mixture of copper sulphide $(27 \% \mathrm{wt})$, silver carbonate $(7 \% \mathrm{wt})$ and kaolin $(66 \% \mathrm{wt})$. Kaolin was calcined at $1000^{\circ} \mathrm{C}$ to remove molecular bound water and other combustible matter, such as carbon and was ground before its addition to the paint mixture. Raw materials were mixed with some amount of water and paint mixture was applied with a brush over the lead alkali glazed İznik tile. Furnace was heated slowly up to $550^{\circ} \mathrm{C}$ in oxygen atmosphere, with a waiting period of 5 minutes at that temperature where the glaze partly softens. Reducing atmosphere was applied with introducing 35-80 grams of rosewood through a pinhole of the furnace during cooling stage. Total reducing time was about 5-10 minutes. Finally, after cooling period the samples were taken out of the furnace and the remaining paint was washed out of the surface, revealing the blue-violet luster beneath on the surface of the sample. Fig. 3 shows the over-glazed lustered İznik tile and composition of luster layer which have $360 \mathrm{~nm}$ thicknesses was examined by SEM EDX spectrometer.

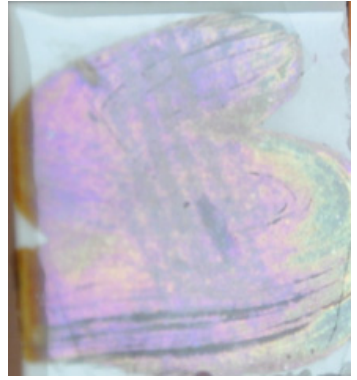

(a)

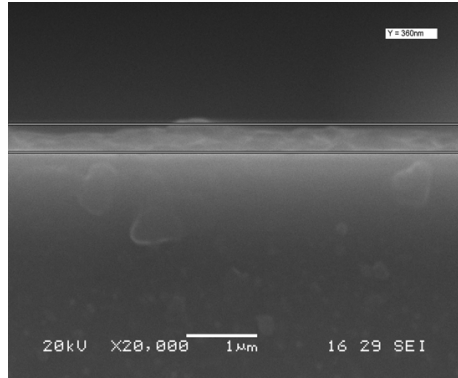

(b)

\begin{tabular}{|l|l|}
\hline Element & wt\% \\
\hline $\mathrm{O}$ & 34.242 \\
\hline $\mathrm{Al}$ & 0.681 \\
\hline $\mathrm{Si}$ & 34.827 \\
\hline $\mathrm{Cu}$ & 2.949 \\
\hline $\mathrm{Ag}$ & 6.918 \\
\hline $\mathrm{Pb}$ & 20.384 \\
\hline Total & 100.000 \\
\hline
\end{tabular}

(c)

Figure 3: (a) Over-glazed luster on lead alkali glazed İznik tiles; (b) SEM micrograph and EDX analysis of luster layer. (The layer thickness is about $360 \mathrm{~nm}$.)

According to the literature; the scatter and absorption of the light by the metal nanoparticles (as described by Mie scattering) is mainly dominated by the so called surface Plasmon resonance adsorption (SPR), with characteristic adsorption peaks which modify the colour, transparency and reflectivity of the layer [4]. The presence of $\mathrm{Ag}^{+}, \mathrm{Cu}^{+}$and $\mathrm{Cu}^{+2}$, either dissolved in the glassy matrix or forming compounds is also responsible for the final colour shown by the luster layer [4]. Also; the increase in the volume fraction of the nanoparticles in the luster layer, is the main reason for the metal-like reflectivity shown by the 
luster layers developed on lead containing glazes [10, 12]. The glaze should contain sodium and potassium to form a metallic layer on glaze by silver and copper within the luster. The molecular structure of the glaze allows sodium and potassium atoms to enter the network. Sodium-potassium-oxygen bond is so strong; carbon monoxide cannot corrupt this bond. So, alkali rich glazes are not affected from intense reductive atmosphere that reduce pigments to metal. When lead glazes are used, especially tin containing lead glazes are easily reduced, even begin to darken [13]. Results of elemental analysis from the surface of İznik tiles are in a good correlation with the literature as shown in Table 6. The ionic exchange took place during the production of luster layer on İznik tiles, sodium content of the lead alkali glaze reduced while copper and silver content is increased with the formation of luster layer. Some amount of silver and copper might be dissolved within the glaze, and not detected from the surface analysis. The surface of İznik tile with over glaze luster was analysed by XRD using the conventional teta/2teta scanning (fig. 4). As can be seen from diffraction pattern; metallic silver and an amorphous phase that comes from the glaze is detected. Conversely, copper is dissolved in the glassy matrix since metallic copper or a compound of cupper was not seen.

Table 6: Chemical composition of İznik tile surface with and without luster glaze layer along with powder mixture of luster paste.

\begin{tabular}{|c|c|c|c|}
\hline \multirow{2}{*}{ Element } & \multicolumn{3}{|c|}{ Chemical composition (wt\%) } \\
\cline { 2 - 4 } & $\begin{array}{c}\text { Lead Alkali } \\
\text { glazed İnik tile }\end{array}$ & Luster paste & $\begin{array}{c}\text { İznik tile with } \\
\text { over glaze luster }\end{array}$ \\
\hline $\mathbf{A g}$ & - & 6.274 & 0.883 \\
\hline $\mathbf{A l}$ & 0.334 & 11.786 & 0.256 \\
\hline $\mathbf{C a}$ & 1.033 & 0.134 & 1.037 \\
\hline $\mathbf{C u}$ & 0.010 & 11.822 & 1.357 \\
\hline $\mathbf{F e}$ & 0.059 & 0.515 & 0.077 \\
\hline $\mathbf{K}$ & 0.120 & 0.168 & 0.144 \\
\hline $\mathbf{M g}$ & 0.315 & - & 0.332 \\
\hline $\mathbf{N a}$ & 2.550 & - & 0.504 \\
\hline $\mathbf{O}$ & 40.020 & 44.788 & 38.749 \\
\hline $\mathbf{P b}$ & Balance & 0.014 & Balance \\
\hline $\mathbf{S}$ & - & 6.739 & - \\
\hline $\mathbf{S i}$ & 18.430 & 17.246 & 18.334 \\
\hline $\mathbf{Z r}$ & 0.087 & 0.009 & 0.094 \\
\hline $\mathbf{B a}$ & - & 0.008 & - \\
\hline $\mathbf{C r}$ & - & 0.032 & - \\
\hline $\mathbf{M n}$ & - & 0.006 & - \\
\hline $\mathbf{P}$ & - & 0.098 & - \\
\hline $\mathbf{S r}$ & - & 0.075 & - \\
\hline $\mathbf{T i}$ & - & 0.274 & - \\
\hline $\mathbf{Z n}$ & - & 0.012 & - \\
\hline
\end{tabular}




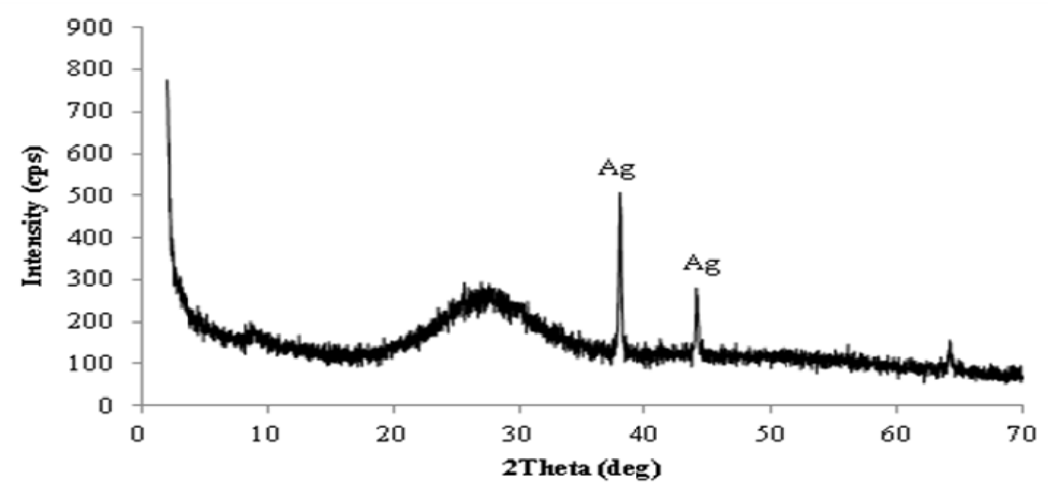

Figure 4: X-ray diffraction pattern of over-glaze luster layer on İznik tile.

\section{Conclusions}

İznik tiles were produced by dry pressing. Bisque firing at $1000^{\circ} \mathrm{C}$, glost firing at $950^{\circ} \mathrm{C}$ was carried out. Traditional pigments were reduced to nano size by introducing mechanical crushing. İznik tiles were painted with both traditional and nanometersized paints for decorating. The colours and gloss measurement showed that more glossy surfaces were obtained with nanometersized paints by both parallel and perpendicular to the brush trace. Colour performance of tiles affected positively by using nanometersized paints and İznik tiles decorated with nanometersized paints were more vivid. In-glaze luster was successfully produced with 5\% silver carbonate (by weight of the glaze) addition to lead alkali glaze of İznik tiles. Rosewood was used as a reducing material to create an oxygen free atmosphere inside the furnace. Reduction temperature was in between $700-600^{\circ} \mathrm{C}$ and reduction time was about 5 minutes. İznik tile with inglaze luster demonstrates yellow iridescent colour because of the metallic silver particles. Silver was also determined with the phase analysis. Over-glaze luster on İznik tile was successfully produced with a luster paint of a mixture which consists of copper sulphide, silver carbonate and calcined kaolin. Firing temperature of $550^{\circ} \mathrm{C}$ in oxygen atmosphere with a waiting period of 5 minutes was applied first. Then during cooling stage 35-80 grams of rosewood used for reducing atmosphere. Over-glaze luster layer obtained with blue-violet colour, $360 \mathrm{~nm}$ thickness and characteristic metal-like reflectivity.

The present results are the first pioneering work of nanometer sized pigment applications on the decoration of İznik tiles and first luster application on İznik tiles within the known literature. It is also hoped that the project results with more characterisation tests (XPS, HRTEM) on the samples will be a good harmony between nanotechnology and the cultural heritage. 


\section{Acknowledgements}

This research has been undertaken as a part of the TUBITAK 1001 (The Support Program for Scientific and Technological Research Projects) program and titled as "Advancing İznik Tiles (Our Cultural Heritage) to the $21^{\text {st }}$ century by Applying Nano-Science and Advanced Nano-Structured Materials-110M190”. The authors are grateful to TUBITAK for financial support, Prof. Sevim Çizer for valuable discussions, Yusuf Öztürk, Emre Karabeyoğlu and Cemalettin Çamyurdu for some of the tests.

\section{References}

[1] Aslanapa, O., Yetkin S. \& Altun, A., İznik Ceramic kiln excavation, II Period 1981-1988, Ankara: Historical Research and Documentation Foundation Publisher, 1989, (in Turkish).

[2] Erhard, D., Not So New Technology, News \& Views, NatureInternational Weekly Journal of Science, pp. 509-510, 2003.

[3] Smith, A. C., Lustre Pottery, New Amsterdam Books, New York, 1991.

[4] Pradell, T., Molera, J., Smith, A.D., Climent-Font, A. \& Tite, M.S., Technology of Islamic Lustre, Journal of Cultural Heritage, 9, pp. 123$128,2008$.

[5] Çizer, S., History, Technique and Art of Luster, Dokuz Eylül University, Faculty of Fine Arts, Narlıdere, İzmir, 2010, (in Turkish).

[6] Heritage: İznik tile-Reflection of İznik tiles to present, Bulletin of Ceramic Foundation, 25, p.p. 104-107, 2008, (in Turkish).

[7] Cavalcante, P.M.T., Dondi, M., Guarini, G., Raimondo, M. \& Baldi G., Colour Performance of Ceramic Nano-Pigments, Dyes and Pigments, 80, pp. 226-232, 2009.

[8] Balogh, A., High Stability Ceramic Pigments, Key Engineering Materials, 132-136, pp. 97-100.

[9] Günay, E. \& Sarıüzel, M., A New Approach to İznik Tiles, Materials Testing, 54, pp. 800-806, 2012.

[10] Mason, R.B., Shine Like The Sun. Lustre-painted and Associated Pottery from the Medieval Middle East., In: Bibliotheca Iranica: Islamic Art and Architecture Series, 12 Mazda Publishers, Inc., Cpsta Mesa, Canada, 2004.

[11] Pradell, T., Molera, J., Roque, J., Vendrell-Saz, M., Smith, A.D., Pantos, E. \& Crespo, D., Ionic-exchange Mechanism in the Formation of Medieval Lustre Decorations, J. Am. Ceram. Soc., 88, 5, pp. 1281-1289, 2005.

[12] Smith, A.D., Pradell, T., Roque, J., Vendrell-Saz, M., Dent, A.J. \& Antos, E.P., Colour Variations in $13^{\text {th }}$ Century Hispanic Lustre an EXAFS Study, J. Non-Cryst. Solids, 352, pp. 5353-5361, 2006.

[13] Molera, J., Bayes, C., Roura, P., Crespo, D. \& Pradell, T., Key Parameters in the Production of Medieval Luster Colours and Shines, J. Am. Ceram. Soc., 90, 7, pp. 2245-2254, 2007. 